\title{
CLINICAL PROFILE OF MULTIPLE MYELOMA IN A TERTIARY CARE HOSPITAL OF PESHAWAR, PAKISTAN
}

\section{Shifa Basharat ${ }^{\mid 凶}$, Zufishan Batool', Nosheen Ali'}

\begin{abstract}
OBJECTIVE: To determine demographic and clinico-pathological characteristics of patients suffering from multiple myeloma (MM) in Peshawar, Pakistan.

METHODS: This descriptive, retrospective study was conducted at Pathology Department, Rehman Medical Institute, Peshawar, Pakistan from January 2006 to September 2018. Detailed information of forty patients diagnosed with MM was collected. World Health Organization (WHO) set criterion was utilized to diagnose MM. SPSS version 22 was used for Statistical analysis.
\end{abstract}

RESULTS: Out of 40 patients, $72.5 \%$ were males with male to female ratio of 2.63:I and mean age of patients was $59.26 \pm 13.1$ years. The common presenting complaints were body/bony pain (87.5\%), fatigue $(72.5 \%)$, body tenderness $(45 \%)$ and backache $(42.5 \%)$. Pallor was present in $33(82.5 \%)$ patients. Laboratory studies showed mean hemoglobin level of $8.6 \pm 2.1 \mathrm{~g} / \mathrm{dl}$, anemia (92.5\%), thrombocytopenia (27.5\%) and hypercalcemia (17.5\%). Elevated ESR > 100 was noted in $29(72.5 \%)$ cases. Renal impairment was established in $35 \%$ of patients. Urinary Bence Jones protein was present in 13 (32.5\%). Serum protein electrophoresis showed M band in $39(97.5 \%)$ cases. Lytic lesions were detected in X-rays of 31 (77.5\%) patients. Based on international staging system, nine $(22.5 \%)$ cases were in stage I, $16(40 \%)$ in stage II and I 5 (37.5\%) in stage III.

CONCLUSION: Majority of multiple myeloma patients in our study were in the $6^{\text {th }}$ decade of life. Bone pain and fatigue were the most common presenting symptoms. Anemia and elevated ESR were the most common laboratory parameter. Most of the patients were diagnosed in later stages (stage II and III).

KEY WORDS: Multiple Myeloma (MeSH); Anemia (MeSH); Renal impairment (Non-MeSH); Kidney Diseases (MeSH); Hypercalcemia $(\mathrm{MeSH})$; Thrombocytopenia (MeSH); Hypoalbuminemia (MeSH); Bone Marrow $(\mathrm{MeSH})$; Myeloma Proteins $(\mathrm{MeSH})$.

THIS ARTICLE MAY BE CITED AS: Basharat S, Batool Z, Ali N. Clinical profile of multiple myeloma in a tertiary care hospital of Peshawar, Pakistan. Khyber Med Univ J 2019; I I(3):I52-5. DOI: I0.35845/KMUJ.2019.18790

\section{INTRODUCTION}

$\mathrm{P}$ lasma cell dyscrasias are a group of concomitant derangements causing an abnormally up heaved number of monoclonal plasma cells and documented by the presence of monoclonal immunoglobulin in the blood also known as M-protein.' Multiple myeloma (MM) is the utmost noteworthy and prevent disorder among all plasma cell dyscrasias. ${ }^{2}$ After lymphomas, MM contributes for $1.3 \%$ of all cancer combined and 15\% of blood-related malignancies. MM is predicted to be the second most ubiquitous blood cancer. ${ }^{3}$ Among Asian countries an expeditious elevation in the incidence of multiple myeloma has been noted causing a great disturbance in the health care system of these countries.

In the United States, MM contributes to approximately $\mathrm{I}-2 \%$ of all malignancies and round about $17 \%$ of hematological neoplasm. The yearly occurrence of
I. Pathology Department, Rehman Medical College, Peshawar, Pakistan.

Email凶: shifa.basharat@rmi.edu.pk
Date Submitted:

Date Revised:

Date Accepted:

March 23, 2019

June 02,2019

June 28,2019
$M M$ in the US is approximately 4$5 / 100,000 .{ }^{5}$ Alike occurrence has been reported in the UK and in Europe. ${ }^{6}$ Worldwide, about 154,000 cases and 101,000 deaths per year is attributed to MM. $^{7}$ There is an exaggeration in incidence with age and the average age of diagnosis is revealed to be $65-70$ years. MM is more prevalent in males as compared to females. ${ }^{8}$ There are some genetic and environmental considerations that have been suspected in the etiology and pathogenesis of MM, peculiarly pesticides, radiations and certain chemicals like benzene, asbestos and arsenic. ${ }^{9} \mathrm{MM}$ is presented clinically with exalted serum calcium, lytic lesions of bone and anemia. ${ }^{10}$ The myeloma cells cause an increase in the activity of osteoclasts by releasing certain cytokines which eventually leads to the clinical manifestations such as lytic lesion of the bones, hypercalcemia and ultimately causing pathological fractures.'

As not much data is available regarding the clinical curse or the demographic diversity of MM in Pakistan, this study was planned to determine demographic and clinic-pathological features of patients with multiple myeloma in our setup.

\section{METHODS}

This descriptive retrospective study was brought about at Pathology Department, Rehman Medical Institute, Peshawar, Pakistan from January 2006 to September 2018. Data of forty patients diagnosed with MM were evaluated. World Health Organization (WHO) criterion was opted for the diagnosis of $\mathrm{MM}^{12}$ Diagnosis required meeting three criteria includes:

i). Detection of M-protein in serum or urine.

ii). Bone marrow clonal plasma cells. 
TABLE I: CLINICOPATHOLOGICAL FEATURES OF PATIENTS $(n=40)$

\begin{tabular}{|l|l|c|c|}
\hline \multicolumn{2}{|c|}{ Characteristics } & Frequency & Percentage \\
\hline \multirow{4}{*}{ Age Groups (years) } & $40-50$ & 16 & 40 \\
\cline { 2 - 4 } & $5 \mathrm{I}-60$ & 14 & 35 \\
\cline { 2 - 4 } & $6 \mathrm{I}-70$ & 7 & 17.5 \\
\cline { 2 - 4 } & $>70$ & 3 & 7.5 \\
\hline \multirow{5}{*}{ Gender } & Male & 29 & 72.5 \\
\cline { 2 - 4 } & Female & $1 \mathrm{I}$ & 27.5 \\
\hline \multirow{5}{*}{ Symptoms \& Signs } & Bone and body pain & 35 & 87.5 \\
\cline { 2 - 4 } & Pallor & 33 & 82.5 \\
\cline { 2 - 4 } & Fatigue & 29 & 72.5 \\
\cline { 2 - 4 } & Fever & 18 & 45 \\
\cline { 2 - 4 } & Body tenderness & 18 & 45 \\
\cline { 2 - 4 } & Back pain & 16 & 42.5 \\
\cline { 2 - 4 } & Constipation & 13 & 32.5 \\
\cline { 2 - 4 } & Weight loss & 9 & 27.5 \\
\cline { 2 - 4 } & Nausea and vomiting & 7 & 17.5 \\
\cline { 2 - 4 } & Neurologic deficit & 9 & \\
\hline
\end{tabular}

TABLE II: LABORATORY PARAMETERS OF PATIENTS $(n=40)$

\begin{tabular}{|c|c|c|}
\hline Parameters & Frequency & Percentage \\
\hline Anaemia $(<12 \mathrm{~g} / \mathrm{dl})$ & 37 & 92.5 \\
\hline Thrombocytopenia $\left(<150 \times 10^{9} / L\right)$ & 11 & 27.5 \\
\hline Elevated ESR $(>100)$ & 29 & 72.5 \\
\hline Hypercalcaemia (> II mg/dl) & 7 & 17.5 \\
\hline Elevated serum creatinine level $(2 \mathrm{mg} / \mathrm{dl})$ & 14 & 35 \\
\hline Hypoalbuminemia $(<3.5 \mathrm{~g} / \mathrm{dl})$ & 27 & 67.5 \\
\hline High LDH level (>450 IU/L) & 17 & 42.5 \\
\hline Urinary Bence Jones protein & 13 & 32.5 \\
\hline M band on Serum protein electrophoresis & 39 & 97.5 \\
\hline X-ray lytic lesions & 31 & 77.5 \\
\hline
\end{tabular}

\section{iii). Related organ or tissue impairment.}

A detailed history included name, age, contact details, sex, occupation, marital status, education, and symptoms of MM patients were recorded. A complete workup including blood counts, erythrocyte sedimentation rate, liver function test, renal function test, serum calcium, peripheral smear, bone marrow study, serum protein electrophoresis, urine routine, presence of urine Bence-Jones proteinuria and a skeletal survey were retrieved from patient record. Ethical approval was taken from the Ethical committee of Rehman Medical College, Peshawar.

SPSS version 22 was used to carry out statistical analysis. Categorical quantitative data was presented in terms of frequencies and percentages.
Mean and the standard deviation were reported for numerical quantitative variables.

\section{RESULTS}

During our study period, 40 patients were found to have MM, in which 29 $(72.5 \%)$ were male and rest were females, with male to female ratio of 2.63:I.

Age range was from $40-8$ I years, with a mean age of $59.26 \pm 13$. I years. The common presenting complaints included body and bone pain in 35 $(87.5 \%)$ followed by fatigue in 29 $(72.5 \%)$ patients rest clinical characteristics are summarized in Table I.

Laboratory studies showed anemia $(\mathrm{Hb}$ $<\mathrm{I} 2 \mathrm{~g} / \mathrm{dl})$ in $37(92.5 \%)$ patients, with a mean hemoglobin level of $8.6 \pm 2.1 \mathrm{~g} / \mathrm{dl}$.
Severe anemia was seen in 14(35\%) patients with hemoglobin less than 7 $\mathrm{gm} / \mathrm{dL}, 2 \mathrm{I}(52.5 \%)$ had moderate anemia with a hemoglobin level between 7 to $10 \mathrm{gm} / \mathrm{dL}$ and $5(12.5 \%)$ had mild anemia with a hemoglobin level between I 0 to I $2 \mathrm{gm} / \mathrm{dL}$. Thrombocytopenia (platelets <I50) were detected in $\mathrm{I}$ I $(27.5 \%)$ with mean platelets count of $173 \pm 149 \times 10^{\circ} / \mathrm{L}$. Other laboratory characteristics are summarized in Table II.

Bone marrow examination uncloaked, nine $(22.5 \%)$ cases had bone marrow plasma cell concentration of $<20 \%, 7$ (I7.5\%) between 20\% -30\%, 12 (30\%) between 30\%- 40\%, 7 (I7.5\%) between $40 \%$ to $50 \%$ and 5 (12.5\%) cases $>50 \%$. The mean bone marrow plasma cell concentration was $34 \%$. Based on international staging system (ISS), nine $(22.5 \%)$ cases were found to be in stage I, $16(40 \%)$ were found to be in stage II and I 5 (37.5\%) were in stage III.

\section{DISCUSSION}

Multiple myelomas (MM) are characterized by the cancerous propagation of plasma cells creating a monoclonal immunoglobulin. MM usually evolve in advance ages and majority after the $6^{\text {th }}$ decade involving mostly males. In our study age group was ranged from $40-81$ years, with the mean age of $59.26 \pm 13.1$ years. It corresponds to findings of other local studies with mean age of 59 and 61 years. ${ }^{13,14}$ Similar study from India reported with a mean age of 58.8 years. ${ }^{15}$ however, the median age of MM is high in developed countries with a median age of $72-74$ years. ${ }^{16}$ Environmental and genetics fluctuation could be the cause of between different part of the world.

Majority of patients in our study presented with bone and body aches $(87.5 \%)$ and were pale $(82.5 \%)$. Bone pain was markedly felt in chest or back and sometimes involving extremities, which in most cases $(60 \%)$ was present at the time of diagnosis. The pain does not appear at night except with a change of posture and is mostly initiated by movement. Reduction in patient's height is noticed by several inches 
because of vertebral collapse. There are plasmacytomas of ribs and present as expanding costal lesions or soft tissue masses.

In our study, $92.5 \%$ of patients had anemia, which contributes frequently to weakness and fatigability. According to Kaur P, et al. ${ }^{17}$ anemia is the most frequent clinical manifestation of MM, around $88 \%$ showed hemoglobin below $12 \mathrm{mg} / \mathrm{dl} .{ }^{17}$ In an another study by Kyle RA, et al.' it was reported that normocytic normochromic anemia was present in $73 \%$ at the time of diagnosis while in $97 \%$ somewhere during the course of the disease.' This anemia can be analogous to renal derangement, replacement of bone marrow or can be because of dilution in the case of huge M-protein.

Bone marrow infiltration by myeloma cells can cause thrombocytopenia and be noticed in $15.6 \%$ cases as in previous studies. ${ }^{17}$ Hypercalcemia contemplated as one among the significant diagnostic criteria and was observed in just 17.5\% patients. Hypercalcemia according to Kyle RA, et al.' is found in $28 \%$ of one series of patients suffering from MM at the time of diagnosis; serum calcium was $\geq 11 \mathrm{mg} / \mathrm{dL}$ in $13 \%$ and can require emergent treatment. Binding of the monoclonal protein with calcium may be due to the rise in serum calcium.

In our study renal impairment was found in $35 \%$ of patients, in most one half of the patient's serum creatinine concentration was raised at the time of diagnosis and is $>2 \mathrm{mg} / \mathrm{dl}$; in MM renal failure may be the presenting manifestation. ${ }^{18}$ Myeloma Kidney or hypercalcemia can be important cause of renal failure in MM.

In majority, low serum albumin was found to be $67.5 \%$, the basis for a threestage international staging system that anticipates survival is formed by the combination of serum B2 and albumin. In previous studies for determining disease severity in symptomatic MM, serum albumin level was found to be an important factor. ${ }^{8}$ On serum protein electrophoresis, $97.5 \%$ of patients have an $M$ band and gamma globin region which was the most common site. The majority (97\%) of patients with MM will have a monoclonal protein produced and secreted by the malignant plasma cells, which can be revealed by protein electrophoresis of serum (SPEP) and of urine aliquot (UPEP) from a 24-hour collection combined with immunofixation of the serum and urine.'

In the majority of patients, bone marrow constitutes $10 \%$ or even more clonal plasma cells, because of patchy bone marrow involvement, bone marrow aspiration and biopsy may reveal plasma cell below $10 \%$ in roughly $4 \%$ of patients. For example, a study by Mayo Clinic, plasma cells constituted more than $10 \%$ of all nucleated cells in $96 \%$ of patients but this value ranged from less than 5 percent to almost 100 percent, with a median value of $50 \%$.

\section{CONCLUSION}

Majority of multiple myeloma patients in our study were in the $6^{\text {th }}$ decade of life but a few younger age groups were also involved. Bone pain along with fatigue were the most common presenting symptoms. Anemia and elevated ESR were the most common laboratory parameter. Most of the patients were diagnosed in later stages (stage II and III).

\section{LIMITATIONS}

This was a retrospective study and relatively small sample study and its findings cannot be generalized.

\section{REFERENCES}

I. Kyle RA, Gertz MA, Witzig TE, Lust JA, Lacy MQ, Dispenzieri A, et al. Review of 1027 patients with newly diagnosed multiple myeloma. Mayo Clin Proc 2003;78(I):2I-33. DOI: 10.4065/78.1.21.

2. Wei $A$, Juneja $S$. Bone marrow immunohistology of plasma cell neoplasms. J Clin Pathol 2003; 56(6):406-II. DOI: 10.1 I36/jcp.56. 6.406

3. Rajkumar SV, Dimopoulos MA, Palumbo A, Blade J, Merlini G, Mateos MV, et al. International Myeloma Working Group updated criteria for the diagnosis of multiple myeloma. Lancet Oncol 2014 Nov 1;15(I2): e538-48. DOI:10.10I6/SI4702045(I4)70442-5.

4. Fousad C, Gangadharan KV, Abdulla
MC, Naryan R, Ali MJ. Clinical profile of multiple myeloma in South India. Indian J Med Paediatr Oncol 2018;39(I):62-6. DOI: 10.4103/ ijmpo.ijmpo_57_I7.

5. Siegel RL, Miller KD, Jemal A. Cancer statistics (2018). CA Cancer J Clin 20I8;68(I):7-30. DOI: 10.3322/ caac. 21442 .

6. Sant M, Allemani C, Tereanu C, DeAngelis R, Capocaccia R, Visser O, et al. Incidence of hematologic malignancies in Europe by morphologic subtype: results of the HAEMACARE project. Blood 2010; II6(19):3724-34. DOI: 10.1 182/blood-2010-05-282632.

7. Global Burden of Disease Cancer Collaboration, Fitzmaurice C, Allen C, Barber RM, Barregard L, Bhutta $Z A$, et al. Global, regional, and national cancer incidence, mortality, years of life lost, years lived with disability, and disability-adjusted lifeyears for 32 cancer groups, 1990 to 2015: a systematic analysis for the global burden of disease study. JAMA Oncol 20I7;3(4):524-48. DOI: 10.1001/jamaoncol.2016.5688.

8. Sultan S, Irfan SM, Parveen S, Ali H, Basharat M. Multiple Myeloma: A retrospective analysis of 61 patients from a tertiary care center. Asian Pac J Cancer Prev 2016;17(4): 1833-5. DOI: 10.73I4/apjcp.2016.17.4.1833.

9. Eriksson M, Karlsson M. Occupational and other environmental factors and multiple myeloma: a population based case-control study. $\mathrm{Br} J$ Ind Med 1992;49(2):95-103. DOI: 10.1/36/ oem.49.2.95.

10. Sultan S, Irfan SM, Parveen S, Taufiq U. International Scoring System in Symptomatic Multiple Myeloma: Experience from a Tertiary Care Center. Asian Pac J Cancer Prev 2016;17(4):203I-3. DOI: 10.73|4/ apjcp.20।6.17.4.203।.

II. Sutandyo N, Firna E, Agustina J, Prayogo N, Widjaja L. Clinicopathology Profile and Bone Involvement of Multiple Myeloma Patients in Dharmais National Cancer Hospital, Indonesia. Asian Pac J Cancer Prev 2015;16(15):626I-5. DOI: $10.73 \mid 4 /$ apjcp.20|5.16.15. 6261 .

12. Swerdlow SH, Campo E, Harris NL, 
Jaffe ES, Pileri SA, Stein H, et al. World Health Organization classification of tumours of haematopoietic and lymphoid tissues. $4^{\text {th }}$ ed. Volume 2 : World Health Organization; 2008.

13. Mansoor S, Siddiqui I, Adil S, Nabi Kakepoto G, Fatmi Z, Ghani F. Anion gap among patients of multiple myeloma and normal individuals. Clin Biochem 2007;40(3-4):226-9. DOI: 10.1016/j.clinbiochem.2006.10.011.

14. Basit A, Siddiqui N, Hameed A, Muzaffar N, Athar S. Factors affecting outcome of patients with multiple myeloma. J Ayub Med Coll Abbottabad 20 I 4;26(3):376-9.

I5. Devi AA, Sharma TD, Singh YI, Sonia $\mathrm{H}$. Clinicopathological profile of patients with non-hodgkin's lymphoma at a regional cancer center in Northeast India. J Sci Soc $2017 ; 44$ (3): I $40-4$. DOI: $10.4103 /$ jss.JSS_42_17.

16. Turesson I, Velez R, Kristinsson SY, Landgren $\mathrm{O}$. Patterns of multiple myeloma during the past 5 decades: stable incidence rates for all age groups in the population but rapidly changing age distribution in the clinic. Mayo Clin Proc 2010;85(3):225-30. DOI: $10.4065 / \mathrm{mcp} .2009 .0426$.

17. Kaur P, Shah BS, Baja P. Multiple myelomas: a clinical and pathological profile. Gulf J Oncol 20I4;I(I6): I420.

18. Winearls CG. Acute myeloma kidney. Kidney Int 1995;48(4): I 347-6 I. DOI: 10.1038/ki. | 995.42I.

\section{AUTHORS' CONTRIBUTIONS}

Following authors have made substantial contributions to the manuscript as under:

SB: Concept \& study design, acquisition of data, drafting the manuscript, final approval of the version to be published

ZB: Acquisition, analysis \& interpretation of data, critical review, final approval of the version to be published

NA: Acquisition, analysis \& interpretation of data, final approval of the version to be published

Authors agree to be accountable for all aspects of the work in ensuring that questions related to the accuracy or integrity of any part of the work are appropriately investigated and resolved.

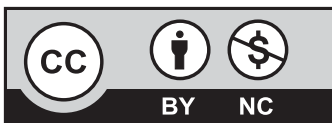

This is an Open Access article distributed under the terms of the Creative Commons Attribution-Non Commercial 2.0 Generic License.

KMUJ web address: www.kmuj.kmu.edu.pk

Email address: kmuj@kmu.edu.pk 